\title{
Corrigendum: Copy Number Heterogeneity in the Virulence Plasmid of Salmonella enterica
}

\author{
María A. Sánchez-Romero *, Ángela Mérida-Floriano and Josep Casadesús* \\ Departamento de Genética, Facultad de Biología, Universidad de Sevilla, Seville, Spain
}

Keywords: Salmonella, virulence plasmid, copy number, phenotypic heterogeneity, noise

\section{A Corrigendum on}

Copy Number Heterogeneity in the Virulence Plasmid of Salmonella enterica

OPEN ACCESS

Approved by:

Frontiers Editorial Office,

Frontiers Media SA, Switzerland

${ }^{*}$ Correspondence: Josep Casadesús

casadesus@us.es

María A. Sánchez-Romero

mtsanchez@us.es

Specialty section:

This article was submitted to

Infectious Diseases,

a section of the journal

Frontiers in Microbiology

Received: 22 December 2020 Accepted: 23 December 2020

Published: 14 January 2021

Citation:

Sánchez-Romero MA,

Mérida-Floriano Á and Casadesús J

(2021) Corrigendum: Copy Number

Heterogeneity in the Virulence Plasmid

of Salmonella enterica.

Front. Microbiol. 11:645054.

doi: 10.3389/fmicb.2020.645054 by Sánchez-Romero, M. A., Mérida-Floriano, Á., and Casadesús, J. (2020). Front. Microbiol. 11:599931. doi: 10.3389/fmicb.2020.599931

In the original article, there was a mistake in the heading of Table 3 as published: in the first column on the left, O.D.600 is incorrect. The correct heading is Time. The corrected Table 3 appears below. In the original article, there was an error in the Abstract. The corrected sentence should read:

In contrast, heterogeneity in the number of foci appears to be independent of the cell volume and may have stochastic origin.

In the Introduction section, paragraph 4, the sentence should read:

Plasmid pSLT has a low ( $\geq 1$ ) copy number per cell (Camacho et al., 2005), etc.

In the Serum Treatment section, the second sentence should read:

Cultures were split into two...

In the Heterogeneity of pSLT Copy Number Along the Growth Cycle, the fifth sentence should read:

Average foci numbers are shown...

In the Effect of pSLT Copy Number Variation on Gene Expression Heterogeneity section, the fifth sentence should read:

variation in GFP expression.

The authors apologize for these errors and state that this does not change the scientific conclusions of the article in any way. The original article has been updated.

Copyright () 2021 Sánchez-Romero, Mérida-Floriano and Casadesús. This is an open-access article distributed under the terms of the Creative Commons Attribution License (CC BY). The use, distribution or reproduction in other forums is permitted, provided the original author(s) and the copyright owner(s) are credited and that the original publication in this journal is cited, in accordance with accepted academic practice. No use, distribution or reproduction is permitted which does not comply with these terms. 
TABLE 3 | Number of plasmid of Salmonella enterica serovar Typhimurium (pSLT) copies per chromosome, determined by qPCR.

\begin{tabular}{lllll}
\hline Time & traJ/arcA & traJ/his $\mathbf{D}^{\mathbf{b}}$ & ccdB/arcA $^{\mathbf{a}}$ & ccdB/his $^{\mathbf{b}}$ \\
\hline 0 & $1.12 \pm 0.23$ & $1.27 \pm 0.32$ & $1.21 \pm 0.12$ & $1.39 \pm 0.08$ \\
60 & $0.92 \pm 0.19$ & $1.06 \pm 0.24$ & $1.03 \pm 0.31$ & $1.16 \pm 0.12$ \\
120 & $1.03 \pm 0.28$ & $1.55 \pm 0.18$ & $1.17 \pm 0.34$ & $1.48 \pm 0.32$ \\
240 & $1.29 \pm 0.11$ & $1.20 \pm 0.35$ & $1.10 \pm 0.26$ & $1.67 \pm 0.29$
\end{tabular}

${ }^{a}$ Averages and standard deviations from 5 independent experiments.

${ }^{b}$ Averages and standard deviations from 3 independent experiments. 